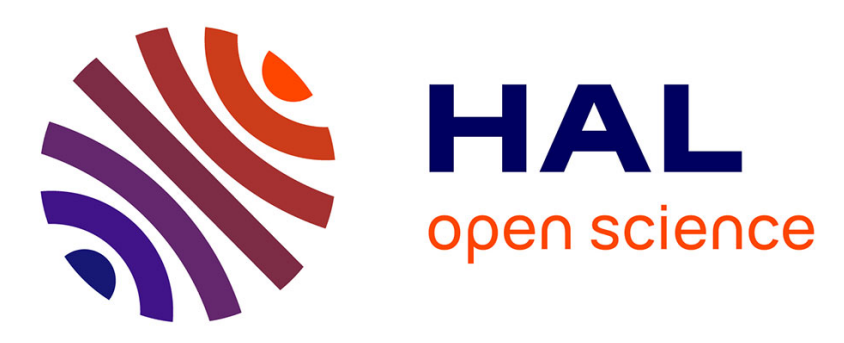

\title{
Sex-biased incidental mortality of albatrosses and petrels in longline fisheries: differential distributions at sea or differential access to baits mediated by sexual size dimorphism?
}

\author{
Leandro Bugoni, Kate Griffiths, Robert W. Furness
}

\section{To cite this version:}

Leandro Bugoni, Kate Griffiths, Robert W. Furness. Sex-biased incidental mortality of albatrosses and petrels in longline fisheries: differential distributions at sea or differential access to baits mediated by sexual size dimorphism?. Journal für Ornithologie = Journal of Ornithology, 2010, 152 (2), pp.261-268. 10.1007/s10336-010-0577-x . hal-00617334

\section{HAL Id: hal-00617334 \\ https://hal.science/hal-00617334}

Submitted on 27 Aug 2011

HAL is a multi-disciplinary open access archive for the deposit and dissemination of scientific research documents, whether they are published or not. The documents may come from teaching and research institutions in France or abroad, or from public or private research centers.
L'archive ouverte pluridisciplinaire HAL, est destinée au dépôt et à la diffusion de documents scientifiques de niveau recherche, publiés ou non, émanant des établissements d'enseignement et de recherche français ou étrangers, des laboratoires publics ou privés. 
Sex-biased incidental mortality of albatrosses and petrels in longline fisheries:

differential distributions at sea or differential access to baits mediated by sexual size dimorphism?

Leandro Bugoni, Kate Griffiths, Robert W. Furness

L. Bugoni (Corresponding author)

Faculty of Biomedical and Life Sciences, Graham Kerr Building, University of Glasgow, Glasgow G12 8QQ, UK

Current address: Universidade Federal do Rio Grande (FURG), Instituto de Ciências

Biológicas, CP 474, 96201-900, Rio Grande, RS, Brazil. e-mail: lbugoni@yahoo.com.br Phone/fax +0055 5332231387

\section{K. Griffiths and R. W. Furness}

Faculty of Biomedical and Life Sciences, Graham Kerr Building, University of Glasgow, Glasgow G12 8QQ, UK 


\begin{abstract}
Skewed Adult Sex Ratio (ASR) has been proposed as a common pattern in birds, frequently biased towards males and with larger biases in globally threatened species. In albatrosses and petrels, it has been suggested that differential mortality of one gender in fisheries is caused either by sexual size dimorphism giving males a competitive advantage, which allows more access of the larger sex (i.e. males) to discards and/or baits, or to at sea segregation of sexes. Here we tested these hypotheses by determining ASRs in albatrosses and petrels trapped at sea when attending longline fishing vessels for discards in the Southwestern Atlantic Ocean, and searched in the literature for patterns in ASR in albatrosses and petrels killed by fisheries in this area and elsewhere. We show that skewed ASR is common in albatrosses and petrels in the community attending vessels for discards, confirming results found for birds in general. There was no correlation between skewed ASR and conservation status, or between ASR and sexual size dimorphism. Our review of the sex of birds incidentally killed in fisheries found skewed ASR toward males, females or parity to be equally reported. Thus, sexual dimorphism in size does not explain skewed ASR in the community we sampled or in incidental captures in fisheries in the review. Differential at sea distribution of sexes appears to be a better explanation of the patterns found in the community sampled at sea as well as skewed ASR in seabird fatalities, particularly distant from breeding areas.
\end{abstract}

Keywords Adult sex ratio; seabirds; incidental capture; longline fishery, sexual dimorphism 


\section{Zusammenfassung}

\section{Geschlechterverschobene zufällige Mortalität von Albatrossen und Sturmvögeln bei der Langleinenfischerei: Unterschiedliche Verteilungen auf See oder unterschiedlicher Zugang zu Ködern aufgrund von sexuellem Größendimorphismus?}

Es ist vorgeschlagen worden, dass ein verschobenes Geschlechterverhältnis von Adulttieren (ASR) ein weitverbreitetes Muster bei Vögeln ist, wobei häufig eine Verschiebung zu Männchen hin erfolgt und die Verschiebungen bei global bedrohten Arten größer sind. Für Albatrosse und Sturmvögel wurde vorgeschlagen, dass differentielle Mortalität eines Geschlechts bei der Fischerei entweder dadurch verursacht wird, dass Männchen aufgrund von sexuellem Größendimorphismus einen Wettbewerbsvorteil haben (derart, dass Männchen als das größere Geschlecht besseren Zugang zu Abfall und/oder Ködern haben), oder durch eine Trennung der Geschlechter auf See. Hier haben wir diese Hypothesen getestet, indem wir die ASR bei Albatrossen und Sturmvögeln ermittelt haben, die auf See gefangen wurden, wenn sie Langleinen-Fischerboote im Südwestatlantik begleiteten, um ins Wasser geworfene Abfälle aufzunehmen. Außerdem haben wir in der Literatur nach Mustern im ASR bei Albatrossen und Sturmvögeln gesucht, die durch Fischerei in diesem Gebiet und anderswo umgekommen sind. Wir zeigen, dass ein verschobenes ASR bei Albatrossen und Sturmvögeln in der Aggregation, die Fischerboote begleitet, häufig ist, was für Vögel im Allgemeinen gefundene Ergebnisse bestätigt. Es bestand keine Korrelation zwischen einem verschobenen ASR und Schutzstatus oder sexuellem Größendimorphismus. Unsere Überprüfung des Geschlechts von Vögeln, die zufällig bei der Fischerei getötet wurden, ergab, dass das ASR gleichermaßen zu Männchen wie zu Weibchen hin verschoben bzw. gar nicht verschoben war. Daher erklärt sexueller Größendimorphismus nicht das verschobene ASR in der 
Aggregation, die wir untersucht haben, oder bei zufälligen Fängen bei der Fischerei. Eine unterschiedliche Verteilung der Geschlechter auf See scheint eine bessere Erklärung sowohl für die in der auf See beprobten Aggregation gefundenen Muster als auch für die verschobenen ASR bei Seevogel-Todesfällen zu sein, insbesondere bei größerer Entfernung von den Brutgebieten.

\section{Introduction}

Sex ratio in birds has received much attention from researchers, often studied at primary (at hatching) and secondary (at fledgling) levels, while tertiary level or adult sex ratio (ASR) is far less known (Mayr 1939; Donald 2007; Becker et al. 2008). In a recent review Donald (2007) emphasized that many questions posed by Mayr (1939) remain unanswered, and reported that skewed ASRs are common in wild bird populations (65\% of studies), with males outnumbering females by around $33 \%$ on average despite offspring sex ratio not differing from parity. An emerging pattern from Donald's review was that globally threatened species are more prone to distortion in ASR, with profound implications for conservation. Procellariiformes (albatrosses, petrels, shearwaters) are a particularly suitable group for testing this latter hypothesis because they are monogamous, extreme $k$-strategist species, i.e. long-lived with low fecundity and low adult mortality, occur in multi-specific flocks, and 
have several threatened and non-threatened species (Marchant and Higgins 1990; Tickell 2000; Brooke 2004).

Unbalanced ASR resulting from skewed mortality impacts on fecundity by reducing effective population size, an effect that persists long after biased mortality ceases in albatrosses (Mills and Ryan 2005). In Wandering Albatross (Diomedea exulans) skewed primary and secondary sex ratios towards males were balanced at recruitment age due to higher mortality of immature males, but again biased towards males at adulthood by a slightly higher mortality of females (Weimerskirch et al. 2005). The higher adult mortality of females is associated with different at sea distribution, males occupying Antarctic waters $\left(50-60^{\circ} \mathrm{S}\right)$ while females are mainly found in subtropical waters $\left(35-45^{\circ} \mathrm{S}\right)$ and overlap more extensively with fisheries (Weimerskirch and Jouventin 1987; Croxall and Prince 1990).

Several studies have reported ASRs of albatrosses and petrels incidentally captured in fisheries, with some reporting skewed ASR towards males (e.g. Ryan and Boix-Hinzen 1999; Nel et al. 2002), some towards females (e.g. Bartle 1990, Roma 2009), variable asymmetry towards either gender, or not differing from parity (e.g. Gales et al. 1998; Gandini and Frere 2006). Reasons for biased sex ratios in fisheries fatalities have been suggested, but not specifically tested. Hypotheses for the discrepancies include different at sea distributions of males and females, and differential access to feeding resources (baits and discards) due to sexual size dimorphism, differential aggressiveness and manoeuvrability. The access to natural food or discard from fisheries is related to body size among seabird species (Hudson and Furness 1988; Ballance et al. 1997), thus we hypothesized that if sexual dimorphism also plays a role in determining ASRs in fishery fatalities (see Ryan and Boix-Hinzen 1999; Nel et al. 2002) ASR will deviate more from parity in species with marked dimorphism, and be similar in closely related species. 
In this study we determined the ASRs and sexual size dimorphism (from Bugoni and Furness 2009) in a number of albatross and petrel species associated with longline fisheries in Brazilian waters. In addition, we reviewed ASRs in Procellariiformes incidentally captured in fisheries in the study area and around the globe. The aims of the study were: a) to determine if there is a pattern in ASR towards males or females in different species attending longliners in the Southwestern (SW) Atlantic Ocean; b) to determine if ASR will deviate more from parity in species with marked dimorphism, and are similar in phylogenetically closely related species; c) to search for patterns in ASR by species and proximity with breeding grounds; d) to test the hypothesis of threatened species being more prone to asymmetry in sex ratio. Whether ASR is more common in threatened species than non-threatened (Donald 2007), we expected to find correlation between the degree of distortion in ASR and the population size, as well as a pattern when comparing closely related species (pairs within the same genus Thalassarche spp. and Procellaria spp.) within the same Red List category, but populations with different orders of magnitude.

To better understand seabird bycatch in the study area we compared sex ratio of birds trapped at sea when attending longline vessels, with sex ratio of birds incidentally killed in the pelagic longline fisheries (same type of vessels), in the same area, years and seasons provided by Roma (2009).

\section{Methods}

Study area and seabird sampling

Albatrosses and petrels $(n=258)$ were attracted close to the vessel using fishing baits and offal (shark liver) and captured non-destructively using a cast net (Bugoni et al. 2008b). 
Seabirds usually attend fishing vessels in the area to scavenge on baits and waste. Vessels were targeting tuna (Thunnus spp.), sharks (mainly Blue Shark Prionace glauca) and Swordfish (Xiphias gladius) through a range of hook-and-line and pelagic longline fishing methods as described by Bugoni et al. (2008c). This fleet operates in deep waters over the continental shelf and in offshore waters in southern Brazil throughout the year (Mayer and Andrade 2005) in the region under the influence of the Subtropical Convergence (Garcia 1998). We captured and sampled birds non-destructively during six cruises and 58 trapping days from February to June 2006 and August-September 2007, from 25 to $35^{\circ} \mathrm{S}$ (Fig. 1).

Molecular sexing

Blood samples $(1 \mathrm{~mL})$ were taken by syringe and needle from the tarsal vein of every bird. Subsamples of blood were stored in $1.5 \mathrm{~mL}$ vials with absolute ethanol. Sexing of birds was carried out after DNA extraction and PCR amplification of CHD genes using primers $2550 \mathrm{~F}$ (Fridolfsson and Ellegren 1999) and 2757R (R. Griffiths, unpublished; Bugoni and Furness 2009) and genes separated in 2\% agarose gel by electrophoresis. DNA extraction negative controls were included for every 23 seabird samples. Positive and negative controls were included for each PCR reaction. One third of all DNA extractions were repeated to confirm gender assignment. Furthermore, we used samples of previously sexed birds as controls: one male Atlantic Yellow-nosed Albatross (Thalassarche chlororhynchos) killed in fisheries and sex determined by necropsy, and four male and female Wandering Albatrosses of known sex from observations at the breeding colony (A. Wood and R.A. Phillips, British Antarctic Survey, in litt.).

Data analysis 
ASR deviations from the expected proportion of 1:1 were tested by ${ }^{2}$ test with Yates' correction for continuity due to only one degree of freedom (Fowler et al. 1998). Trapping methods of birds can bias estimates of ASR (Domènech and Senar 1998). However, Procellariiformes studied here are sexually monomorphic in plumage, thus we were unable to visually detect any sex difference during captures and assumed that samples were representative of the population attending fishing vessels.

Sexual size dimorphism was calculated from biometric measurements of sexed birds in Bugoni and Furness (2009). The percentage of dimorphism between sexes in each trait was calculated as:

$$
\left[\bar{x}_{m} \bar{x}_{f}\right) / \bar{x}_{f} \geq 100
$$

where $\bar{x}_{m}$ and $\bar{x}_{f}$ are mean values for males and females, respectively (Copello et al. 2006). We calculated dimorphism percentages for culmen, wing and tarsus lengths, and pooled the three percentages in a single dimorphism index for each species by calculating the average of these values. Tail and body mass were not used because we found the former a poor descriptor of dimorphism (Bugoni and Furness 2009) and the latter is very variable according to status of birds (Croxall 1995). Species included in the analyses attended fishing vessels for discards and most had been previously recorded to be incidentally captured in longline fisheries in the area (Bugoni et al. 2008a, c).

Values of population size of seabird species to be correlated with degree of ASR was obtained from the literature, taking into account the origin of birds found in SW Atlantic Ocean: Black-browed Albatross Thalassarche melanophris from Falkland Islands; Whitechinned Petrel Procellaria aequinoctialis from South Georgia; Atlantic Yellow-nosed 
Thalassarche chlororhynchos, Great Shearwaters Puffinus gravis, and Spectacled petrels Procellaria conspicillata from Tristan da Cunha Islands; Cape Petrel Daption capense, the global population as the origin of SW Atlantic birds is unknown and there is no estimate for the Atlantic Sector (D. c. capense). Conservation status follows categories proposed by IUCN (2009), with levels of threat, in increasing order as: least concern, near-threatened, vulnerable, endangered and critically endangered.

\section{Results}

All birds $(n=258)$ from the six species studied here, i.e. Atlantic Yellow-nosed Albatross, Black-browed Albatross, White-chinned Petrel, Spectacled Petrel, Great Shearwater and Cape Petrel, plus 41 individuals from other eight petrel and albatross species were successfully sexed using PCR methods, with no discrepancy between controls and replicates, confirming the reliability of the PCR-based method and primers for sexing Procellariiformes.

Three species (Atlantic Yellow-nosed Albatross, White-chinned Petrel and Great Shearwater) had ASR not deviating from parity, while three species had biased ASR: Blackbrowed Albatross towards females, Cape Petrel and Spectacled Petrel towards males (Table $1)$.

Cape Petrel and Great Shearwaters are species not threatened by extinction, and only the former species had skewed ASR (toward males). Amongst the remaining species, two had even ASR, while one had skewed ASR towards females and one towards males. Pairs of threatened species phylogenetically closely related (Thalassarche albatrosses and Procellaria petrels), show contrasting results: one species of each pair with skewed ASR (Table 1).

Average sexual size dimorphism varied from $1.3 \%$ in Great Shearwater to $4.1 \%$ in Spectacled Petrel, with larger males in all species (Table 2). The degree of sexual dimorphism 
was not correlated with the level of asymmetry in ASR neither with the population size (Spearman correlation coefficient $\mathrm{r}_{\mathrm{s}}=0.6, P=0.2, \mathrm{n}=6, \mathrm{r}_{\mathrm{s}}=-0.3, P=0.5, \mathrm{n}=6$, respectively) (Table 1).

Eighteen published studies reported ASR of eight albatrosses, four petrel and one shearwater species captured in bottom and pelagic longline fisheries (Table 3). Studies frequently tested for ASR in several species or carried out stratified analysis by season and area. Skewed ASR in Procellariiformes was reported more frequently than parity ( ${ }^{2}$ Yates $=$ 4.33, $P=0.04$ ), but considering the three possible results, males were reported $36 \%$, females $26 \%$ and parity $38 \%$ parity, thus no tendency was found towards any gender or parity to be reported more frequently $\left({ }_{2}^{2}=1.17 P=0.56\right)$.

\section{Discussion}

In the present study we showed skewed ASR in a number of species of albatrosses and petrels associated with longliners operating in Brazilian waters and offshore. However, our results failed to demonstrate an association between skewed ASR and conservation status, both in terms of population size or level of threat, as suggested by Donald (2007). Determination of ASR may be subject to a number of biases (Donald 2007), but sampling and determining sex of a range of species occurring simultaneously in the same area using the same method appears to be adequate to test the hypothesis proposed by Donald (2007) and propose alternative ones, such as differential distribution and sexual size dimorphism.

Sexual size dimorphism also failed to explain why pairs of closely related species (White-chinned and Spectacled Petrels; Atlantic Yellow-nosed and Black-browed Albatrosses) have contrasting sex ratios. Furthermore, while we found unbiased sex ratio for the White-chinned Petrels captured non-destructively, Roma (2009) found more females 
being killed in the pelagic longline fishery in the same area, during the same period and seasons. Whether the large males have preference in access to baits, as occurs with larger species to discards in this fishery and others (Hudson and Furness 1988; Votier et al. 2004), and postulated to explain male-biased mortality around colonies (e.g. Ryan and Boix-Hinzen 1999; Nel et al. 2002) one would expect biased mortality toward males in the SW Atlantic Ocean, or at the least a result similar to the proportion of sexes in the area. For Black-browed Albatross in this area, both incidental mortality and our sampling were biased toward females. Explanation for this pattern of female-bias could be the predominance of females in the area. Because Black-browed Albatross juveniles predominated in both bycatch (Roma 2009) and our samples (Bugoni and Furness 2009) it could be argued that there is no sex-related hierarchy due to similar aggressiveness between sexes at this life-stage. However, if this is true, and there is a similar proportion of both sexes in the area, one would expect to find unbiased sex-ratios in Roma (2009) and the present study, again supporting the hypothesis of differential distribution of sexes at sea.

Sexual size dimorphism was not correlated with the degree in ASR, thus both sexes seem to have similar access to baits and discards, even in species with more marked dimorphism in size. The hierarchy in access to discards in seabird communities is based on body size (Ballance et al. 1997; Barnes et al. 1997) and this is also clear in our study area, where the preferential access to feeding discards is Diomedea $>$ Thalassarche/Macronectes $>$ Procellaria $>$ Puffinus $>$ Daption/Fulmarus (author's, pers. observ.). However, it is probable that the magnitude of the intraspecific sexual size dimorphism in this community, and in the access to hooked baits elsewhere (see discussion on ASR review below), is not large enough to account for a male dominancy in the species studied here. On the other hand, the dimorphism could have implications in the different access to baited hooks while sinking underwater for diving species such as Puffinus shearwaters or Procellaria petrels. 
There was no pattern of skewed mortality towards males in the range of ASR mortality reported in the literature, with parity, male bias and female bias being equally reported. Male biased mortality of White-chinned Petrel, Grey-headed (Thalassarche chrysostoma) and Indian Yellow-nosed Thalassarche carteri) Albatrosses reported by Ryan and Boix-Hinzen (1999) and confirmed with a larger data set for these species plus Grey Petrel, Procellaria cinerea (Nel et al. 2002) was recorded in longline fisheries around Prince Edward Islands, where these species breed. As central-place foragers, both males and females should return to the nest for incubation or chick rearing, thus both sexes are obliged to occur around the colony. Results differed in other studies with these species (Table 3) on mortality in fisheries within the foraging range of breeding birds, such as in New Zealand and Australia (Bartle 1990; Murray et al. 1993; Gales et al. 1998), suggesting that the larger size of males or higher male aggressiveness do not play an important role. The most detailed study (Gales et al. 1998) tested for ASR in different areas and seasons and found that some species are skewed during one season or in one area but show even ASR in other areas or seasons. Those species analysed in several studies (e.g. White-chinned Petrel, Black-browed Albatross) showed biased ASR towards males, females and no bias according to season or area. Furthermore, the mortality in longline fisheries of the Black-browed Albatross from the Falkland/Malvinas Islands population, is unbiased within the foraging range of breeding birds (Gandini and Frere 2006; Reid et al. 2004; Seco-Pon et al. 2007), but female-biased further north off the Brazilian coast in longline catches (Neves and Olmos 1998; Roma 2009) and attending longliners for discards (this study), indicating the role of differential distribution of sexes outside foraging range of breeding areas. The White-chinned Petrel, a species frequently killed in fisheries in several areas, also seems to have skewed male-biased mortality in fisheries around breeding colonies as mentioned above (see also Delord et al. 2005 around Crozet Kerguelen Islands), but not confirmed by Gandini and Frere (2006) and 
Seco-Pon et al. (2007), while in wintering grounds it is female-biased or have even ASR (Neves and Olmos 1998; Roma 2009; current study). Further studies comparing ASR around breeding grounds and in wintering grounds are warranted.

An alternative hypothesis to explain ASR in longline fatalities is differential at sea distribution of males and females. Sexual segregation in foraging areas of seabirds during the breeding period has been clearly demonstrated in some Procellariiformes, such as Southern Giant Petrel and Northern Giant Petrel (Macronectes halli) (González-Solís et al. 2008), Black-browed and Grey-headed Albatrosses (Phillips et al. 2004), Southern Buller's Albatross (Thalassarche bulleri) (Stahl and Sagar 2000a), and suggested in other studies (Bartle 2000; Shaffer et al. 2001; Weimerskirch et al. 2005). Moreover, differential at sea distribution during wintering periods has been argued as responsible for sex biases in albatrosses and petrels washed ashore (Holmes 1981) or driven inland by storm (Bugoni et al. 2007), yet not demonstrated in some species or populations (e.g. Anderson et al. 1998; Stahl and Sagar 2000b).

Studies on other seabirds (including gulls, terns, penguins, auks and cormorants) suggest that males and females share foraging areas, but show niche segregation in other dimensions such as foraging depth and prey size (e.g. Wernham et al. 2002; Phillips et al. 2004 and references therein). Albatrosses, petrels and shearwaters disperse over vast areas far from breeding grounds, which could play a role in explaining sexual and age-related at-sea segregation, both by competitive exclusion or habitat specialization. Differential distribution could be an important factor in skewed ASR in albatross and petrel communities and in samples of birds captured in longline fisheries.

Differential mortality of one gender is of serious conservation concern for threatened seabirds such as albatrosses (Mills and Ryan 2005) of which 19 out of 21 species are threatened by extinction (BirdLife International 2004). Due to the effects caused by 
asymmetrical mortality on threatened populations by reducing effective population size, this topic deserves further study on a species-specific basis. In addition, ASR could vary if the sample of incidentally killed birds is from around breeding grounds where adults predominate, or elsewhere, where juveniles predominate or age classes are mixed. In contrast to other seabird taxa, sexual segregation of albatrosses and petrels at sea appears to be a widespread pattern, which could explain most differential captures in fisheries. It is therefore recommended that fisheries observers retain seabirds killed in fishing operations for analysis of age, sex and breeding status.

Acknowledgements Thanks to Captain Celso Oliveira and crew of the fishing vessels "Ana Amaral I" and 'Akira V' for logistic support onboard. Authors are grateful to Richard Griffiths who provided the primer 2757R used in this study, Richard Phillips for comments on a previous draft of this manuscript and two anonymous reviewers. LB received a CAPES Scholarship. This study was carried out according to permits No. 0128931BR, No. 203/2006, No. $02001.005981 / 2005$, No. $023 / 2006$, No. $040 / 2006$ and No. $1282 / 1$, all granted by the Brazilian Environmental Agency (IBAMA), and International Animal Health Certificate No. 0975-06, issued by the Brazilian Government. The Scottish Executive - Rural Affairs Directorate also kindly provided us permit POAO 2007/91 to import samples into Scotland.

\section{References}

Anderson DJ, Schwandt AJ, Douglas HD (1998) Foraging ranges of Waved Albatrosses in the eastern tropical Pacific. In: Robertson G, Gales R (eds), Albatross biology and conservation. Chipping Norton, Surrey Beatty \& Sons, pp 180-185

Awkerman JA, Huyvaert KP, Mangel J, Shigueto JA, Anderson DJ (2006) Incidental and intentional catch threatens Galápagos Waved Albatross. Biol Conserv 133:483-489 
Ballance LT (2007) Understanding seabirds at sea: why and how? Mar Ornithol 35:127-135

Ballance LT, Pitman RL, Reilly SB (1997) Seabird community structure along a productivity gradient: importance of competition and energetic constraint. Ecology 78:1502-1518

Barnes KN, Ryan PG, Boix-Hinzen C (1997) The impact of the hake Merluccius spp. longline fishery off South Africa on procellariiform seabirds. Biol Conserv 82:227-234

Bartle JA (1990) Sexual segregation of foraging zones in procellariiform birds: implications of accidental capture on commercial fishery longlines of Grey Petrels (Procellaria cinerea). Notornis 37:146-150

Becker PH, Ezard THG, Ludwigs JD, Sauer-Gürth H, Wink M (2008) Population sex ratio shift from fledging to recruitment: consequences for demography in a philopatric seabird. Oikos 117:60-68

BirdLife International (2004) Tracking ocean wanderers: the global distribution of albatrosses and petrels. Results from the Global Procellariiform Tracking Workshop, 1-5 September, 2003, Gordon's Bay, South Africa. Cambridge: BirdLife International

BirdLife International (2010) Species factsheets Downloaded from http://www.birdlife.org (Assessed on 02 June 2010)

Brooke M (2004) Albatrosses and petrels across the world. Oxford University Press, New York.

Bugoni L, Furness RW (2009) Age composition and sexual size dimorphism of albatrosses and petrels off Brazil. Mar Ornithol 37:253-260

Bugoni L, Sander M, Costa ES (2007) Effects of the first southern Atlantic hurricane on Atlantic Petrels (Pterodroma incerta). Wilson J Ornithol 119:725-729

Bugoni L, Neves TS, Leite-Jr NO, Carvalho D, Sales G, Furness RW, Stein CE, Peppes FV, Giffoni BB, Monteiro DS (2008a) Potential bycatch of seabirds and turtles in hook-andline fisheries of the Itaipava Fleet, Brazil. Fish Res 90:217-224 
Bugoni L, Neves TS, Peppes FV, Furness RW (2008b) An effective method for trapping scavenging seabirds at sea. J Field Ornithol 79:308-313

Bugoni L, Mancini PL, Monteiro DS, Nascimento L, Neves TS (2008c) Seabird bycatch in the Brazilian pelagic longline fishery and a review of capture rates in the southwestern Atlantic Ocean. Endang Species Res 5:137-147

Burg T (2008) Genetic analysis of Wandering Albatrosses killed in longline fisheries off the east coast of New Zealand. Aquatic Conserv: Mar Freshw Ecosyst 17:S93-S101

Copello S, Quintana F, Somoza G (2006) Sex determination and sexual size-dimorphism in Southern Giant-petrels (Macronectes giganteus) from Patagonia, Argentina. Emu $106: 141-146$

Croxall JP (1995) Sexual size dimorphism in seabirds. Oikos 73:399-403

Croxall JP, Prince PA (1990) Recoveries of Wandering Albatrosses Diomedea exulans ringed at South Georgia 1958-1986. Ringing \& Migration 11:43-51

Delord K, Barbraud C, Weimerskirch H (2010) Multivariate effects on seabird bycatch in the legal Patagonian toothfish longline fishery around Crozet and Kerguelen Islands. Pol Biol $33: 367-378$

Delord K, Gasco N, Weimerskirch H, Barbraud C, Micol T (2005) Seabird mortality in the Patagonian toothfish longline fishery around Crozet and Kerguelen Islands, 2001-2003. CCAMLR Sci 12:53-80

Domènech J, Senar JC (1998) Trap type can bias estimates of sex ratio. J Field Ornithol 69:380-385

Donald PF (2007) Adult sex ratios in wild bird populations. Ibis 149:671-692

Fowler J, Cohen L, Jarvis P (1998) Practical statistics for field biology. $2^{\text {nd }}$ Edition, John Wiley \& Sons, Chichester 
Fridolfsson AK, Ellegren H (1999) A simple and universal method for molecular sexing of non-ratite birds. J Avian Biol 30:116-121

Gales R, Brothers N, Reid T (1998) Seabird mortality in the Japanese tuna longline fishery around Australia, 1988-1995. Biol Conserv 86:37-56

Gandini P, Frere E (2006) Spatial and temporal patterns in the bycatch of seabirds in the Argentinian longline fishery. Fish Bull 104:482-485

Garcia CAE (1998) Oceanografia física. In Seeliger U, Odebrecht C, Castello JP (eds) Os ecossistemas costeiro e marinho do extremo sul do Brasil. Ecoscientia, Rio Grande, pp $104-106$

González-Solís J, Croxall JP, Afanasyev V (2008) Offshore spatial segregation in Giant Petrels Macronectes spp.: differences between species, sexes and seasons. Aquatic Conserv 17:S22-S36

Holmes G (1981) Unequal sex ratios among seabirds found beached-washed. Emu 81:44-47

Hudson AV, Furness RW (1988) Utilization of discarded fish by scavenging seabirds behind whitefish trawlers in Shetland. J Zool, Lond 215: 151-166

Huin N, Reid T. (2007) Census of the Black-browed Albatross population of the Falkland Islands, 2000 and 2005. Stanley: Falklands Conservation

IUCN (2009) 2009 IUCN Red List of Threatened Species. version 2009.2. http://www.iucnredlist.org (downloaded on 09 February 2010)

Marchant S, Higgins PJ (1990) Handbook of Australian, New Zealand and Antarctic birds. Oxford University Press, Melbourne

Martin AR, Poncet S, Barbraud C, Foster E, Fretwell P, Rothery P (2009) The Whitechinned Petrel (Procellaria aequinoctialis) on South Georgia: population size, distribution and global significance. Polar Biol 32:655-661 
Mayer FP, Andrade HA (2005) Swordfish (Xiphias gladius) and blue shark (Prionace glauca) fishery and the dynamics of the fleet off the southeastern Brazilian coast. Col Vol Sci Pap ICCAT 58:1204-1214

Mayr E (1939) The sex ratio in wild birds. Am Natur 73:156-179

Mills MSL, Ryan PG (2005) Modelling impacts of long-line fishing: what are the effects of pair-bond disruption and sex-biased mortality on albatross fecundity? Anim Conserv $8: 359-367$

Murray TE, Battle JA, Kalish SR, Taylor PR (1993) Incidental capture of seabirds by Japanese southern bluefin tuna longline vessels in New Zealand waters, 1988-1992. Bird Conserv Internat 3:181-210

Nel DC, Ryan PG, Watkins BP (2002) Seabird mortality in the Patagonian toothfish longline fishery around Prince Edward Island, 1996-2000. Antarct Sci 14:151-161

Neves T, Olmos F (1998) Albatross mortality in fisheries off the coast of Brazil. In: Robertson G, Gales R (eds), Albatross biology and conservation. Chipping Norton, Surrey Beatty \& Sons, pp 214-219

Phillips RA, Silk JRD, Phalan B, Catry P, Croxall JP (2004) Seasonal segregation in two Thalassarche albatross species: competitive exclusion, reproductive role specialization or foraging niche divergence? Proc R Soc Lond B 271:1283-1291

Reid TA, Sullivan BJ, Pompert J, Enticott JW, Black AD (2004) Seabird mortality associated with Patagonian Toothfish (Dissostichus eleginoides) longliners in Falkland Islands waters. Emu 104:317-325

Roma CR (2009) Composição sexual e etária do Albatroz-de-sobrancelha-negra Thalassarche melanophrys [sic] e da Pardela-preta Procellaria aequinoctialis (Ordem: Procellariiformes) do Sul-Sudeste do Brasil. Unpubl. dissertation, Santos, Unimonte. 
Ryan PG, Boix-Hinzen C (1999) Consistent male-biased seabird mortality in the Patagonian toothfish longline fishery. Auk 116:851-854

Ryan PG, Dorse C, Hilton GM (2006) The conservation status of the Spectacled Petrel Procellaria conspicillata. Biol Conserv 131:575-583

Seco-Pon JP, Gandini PA, Favero M (2007) Effect of longline configuration on seabird mortality in the Argentine semi-pelagic kingclip Genypterus blacodes fishery. Fish Res $85: 101-105$

Shaffer SA, Weimerskirch H, Costa DP (2001) Functional significance of sexual dimorphism in Wandering Albatrosses, Diomedea exulans. Funct Ecol 15:203-210

Stahl JC, Sagar PM (2000a) Foraging strategies of southern Buller's Albatrosses Diomedea b. bulleri breeding on the Snares, New Zealand. J R Soc NZ 30:299-318

Stahl JC Sagar PM (2000b) Foraging strategies and migration of southern Buller's Albatrosses Diomedea b. bulleri breeding on the Solander Islands, New Zealand. J R Soc NZ 30:319-334

Thalmann S, Baker GB, Hindell M, Double MC, Gales R (2007) Using biometric measurements to determine gender of flesh-footed shearwaters, and their application as a tool in long-line by-catch management and ecological field studies. Emu 107:231-238

Tickell WLN (2000) Albatrosses. Pica Press, Sussex

Votier SC, Furness RW, Bearhop S, Crane JE, Caldow RWG, Catry P, Ensor K, Hamer KC, Hudson AV, Kalmbach E, Klomp NI, Pfeiffer S, Phillips RA, Prieto I, Thompson DR (2004) Changes in fisheries discard rates and seabird communities. Nature 427:727-730 Weimerskirch H, Jouventin P (1987) Population dynamics of the Wandering Albatross Diomedea exulans, of the Crozet Islands: causes and consequences of the population decline. Oikos 49:315-322 
Weimerskirch H, Lallemand J, Martin J (2005) Population sex ratio variation in a monogamous long-lived bird, the Wandering Albatross. J Anim Ecol 74:285-291

Wernham C, Roms M, Marchant J, Clark JA, Siriwardena GM, Baillie S (eds) (2002) The migration atlas: movements of the birds of Britain and Ireland. T \& AD Poyser, London 
Table 1 Sex ratio and status of conservation of albatrosses and petrels sampled at sea in 2006 and 2007 in the Southwestern Atlantic Ocean. For all tests degrees of freedom $-\mathrm{df}=1$

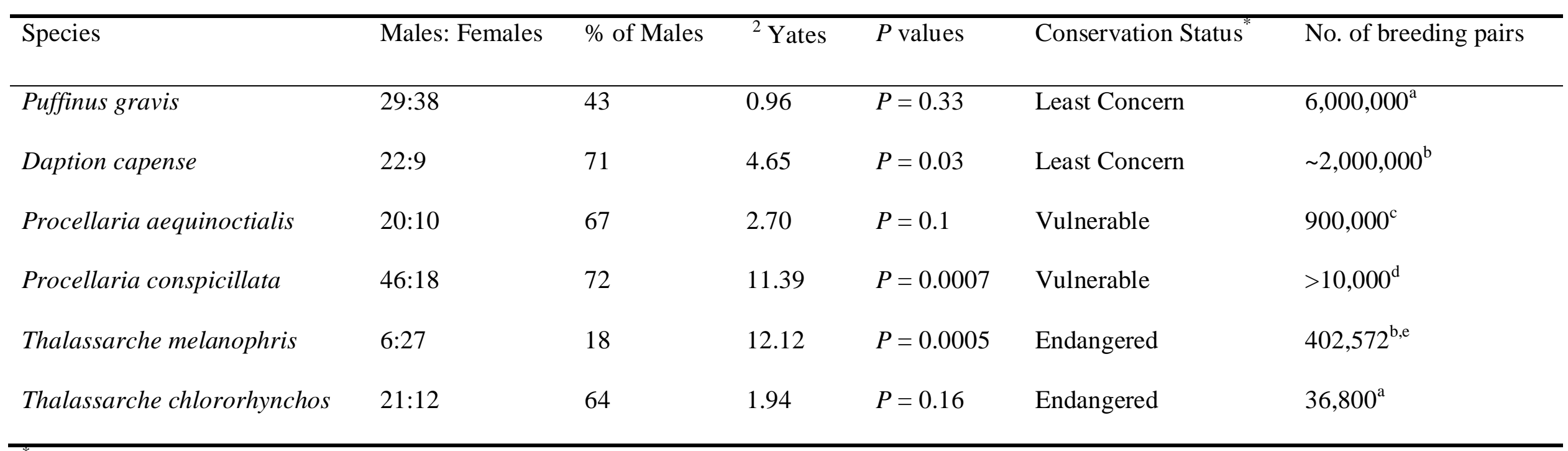

* According to IUCN Red List Category.

${ }^{1}$ Population estimates: ${ }^{\mathrm{a}}$ Brooke (2004); ${ }^{\mathrm{b}}$ BirdLife International (2010); ${ }^{\mathrm{c}}$ Martin et al. (2009); ${ }^{\mathrm{d}}$ Ryan et al. (2006); ${ }^{\mathrm{e}}$ Huin and Reid (2007) 
Table 2 Percentage of sexual size dimorphism (SSD) in external body measurements of albatrosses and petrels sampled at sea off Brazil

\begin{tabular}{llllll}
\hline Species & $n$ & Culmen & Tarsus & Wing & Average SSD \% \\
\hline Puffinus gravis & 67 & 2.6 & 1.4 & -0.15 & 1.3 \\
Daption capense & 31 & 3.3 & 4.0 & 1.8 & 3.0 \\
Procellaria aequinoctialis & 30 & 3.6 & 1.2 & 1.2 & 2.0 \\
Procellaria conspicillata & 64 & 6.1 & 3.1 & 3.0 & 4.1 \\
Thalassarche melanophris & 33 & 0.5 & 3.0 & 3.5 & 2.3 \\
Thalassarche chlororhynchos & 33 & 4.5 & 5.5 & 2.0 & 4.0 \\
\hline
\end{tabular}


Table 3 Review of adult sex ratios of albatrosses and petrels incidentally captured in fisheries. The number of times a given result was reported (not skewed or towards each gender) is given

\begin{tabular}{|c|c|c|c|c|}
\hline Species & Skewed towards & Fishery Type & Location of the study & Reference \\
\hline \multirow{4}{*}{ (Diomedea exulans) } & & & Uruguayan coasts & \\
\hline & Not skewed & Pelagic longline & Australia & Gales et al. (1998) \\
\hline & Females (skewed & Attributed to trawlers & Crozet Island & Weimerskirch and Jouventin \\
\hline & towards males in & (colonies) & & (1987) and Weimerskirch et al. \\
\hline \multirow{3}{*}{$\begin{array}{l}\text { Black-browed Albatross } \\
\text { (Thalassarche melanophris) }\end{array}$} & & & & and Olmos (1998) \\
\hline & Females & Pelagic longline & Southern Brazil & Roma (2009) \\
\hline & Not skewed & Bottom longline & Falkland Island & Reid et al. (2004) \\
\hline
\end{tabular}


Not skewed

Not skewed

Bottom longline

Pelagic longline

Pelagic longline

Males (3x)

(Thalassarche impavida)

Albatrosses pooled

Indian Yellow-nosed

Not skewed (2x)

Males

Albatross

(Thalassarche carteri)

Females

Males

Grey-headed Albatross

Males (2x)

(Thalassarche chrysostoma)

Not skewed (2x)

Males

Bottom longline

Bottom longline

Pelagic longline

Pelagic longline

Bottom longline
Patagonian Shelf,

Argentina

Patagonian Shelf,

Seco-Pon et al. (2007)

Argentina

Australia

Australia

Australia

Australia

Australia

Prince Edward Is.

Gandini and Frere (2006)

Gales et al. (1998)

Gales et al. (1998)

Gales et al. (1998)

Gales et al. (1998)

Gales et al. (1998)

Ryan and Boix-Hinzen (1999)

and Nel et al. (2002)

Australia

Gales et al. (1998)

Gales et al. (1998)

Ryan and Boix-Hinzen (1999)

and Nel et al. (2002) 


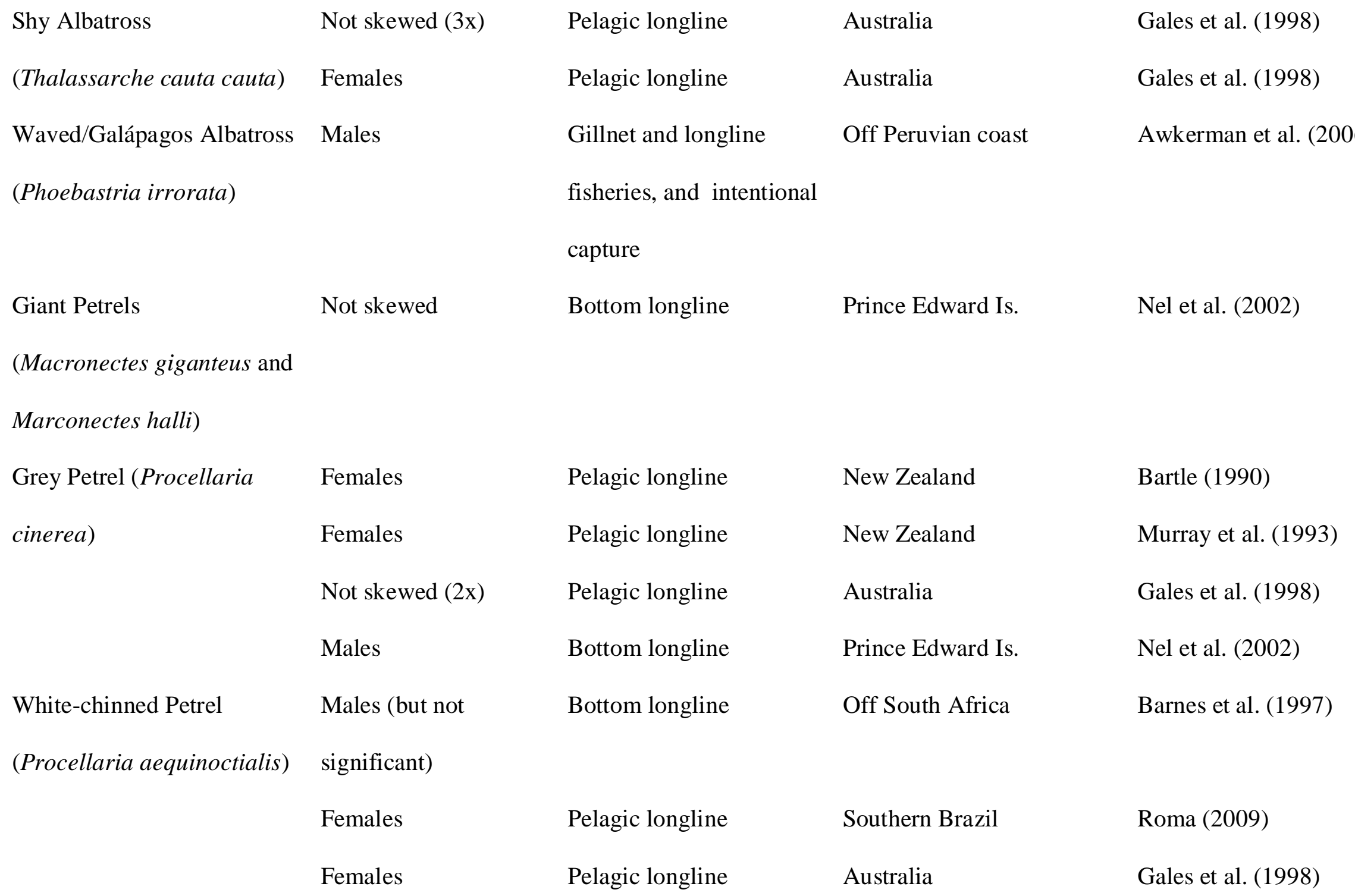


Males

Males

Not skewed

Not skewed

Males

Flesh-footed Shearwater

(Puffinus carneipes)

Females (3x)
Not skewed
Males

Bottom longline

Bottom longline

Bottom longline

Bottom longline

Bottom longline

Pelagic longline

Pelagic longline

Pelagic longline
Prince Edward Is.

Ryan and Boix-Hinzen (1999)

and Nel et al. (2002)

French exclusive EEZ of

Delord et al. (2005)

Crozet and Kerguelen Is.

Patagonian Shelf,

Gandini and Frere (2006)

Argentina

Patagonian Shelf,

Seco-Pon et al. (2007)

Argentina

French exclusive EEZ of

Crozet and Kerguelen Is.

Australia

Australia

Australia
Gales et al. (1998)

Delord et al. (2010)

Gales et al. (1998)

Calculated from data in

Thalmann et al. (2007)

\footnotetext{
${ }^{*}$ Gales et al. (1998) presented sex ratios for season and area
} 


\section{Figure Captions}

Fig. 1 Locations in the Southwestern Atlantic Ocean where albatrosses and petrels attending longline vessels for discards were captured with cast nets and blood-sampled for sex determination. A single location usually represents several sampled birds.

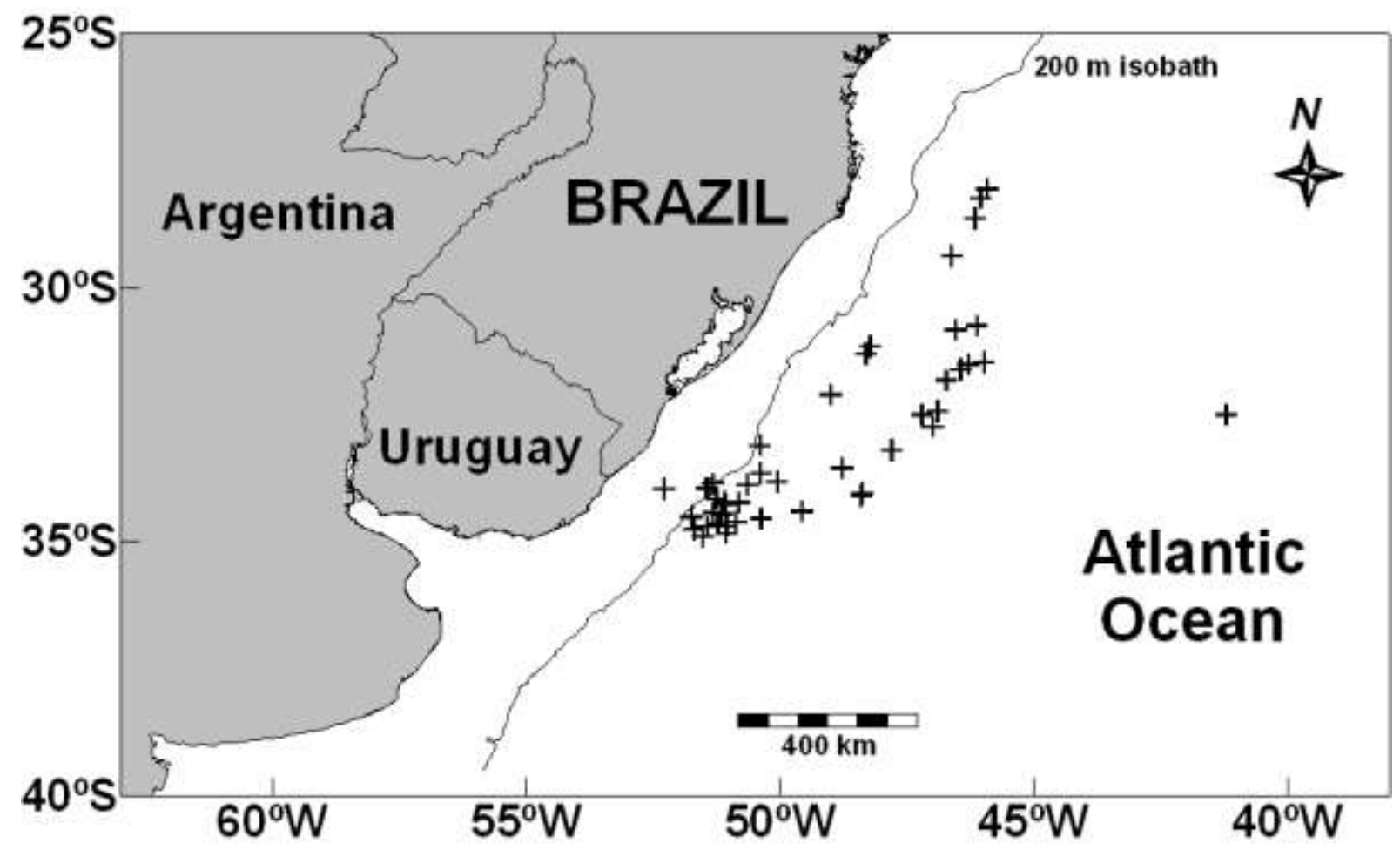

